\title{
Histone deacetylases as new therapy targets for platinum-resistant epithelial ovarian cancer
}

\author{
Dmitri Pchejetski ${ }^{1}$ - Albandri Alfraidi ${ }^{2} \cdot$ Keith Sacco $^{3} \cdot$ Heba Alshaker $^{4}$. \\ Aun Muhammad ${ }^{2} \cdot$ Leonardo Monzon ${ }^{5}$
}

Received: 13 September 2015 / Accepted: 20 October 2015 / Published online: 11 November 2015

(C) The Author(s) 2015. This article is published with open access at Springerlink.com

\begin{abstract}
Introduction In developed countries, ovarian cancer is the fourth most common cancer in women. Due to the nonspecific symptomatology associated with the disease many patients with ovarian cancer are diagnosed late, which leads to significantly poorer prognosis. Apart from surgery and radiotherapy, a substantial number of ovarian cancer patients will undergo chemotherapy and platinum based agents are the mainstream first-line therapy for this disease. Despite the initial efficacy of these therapies, many women relapse; therefore, strategies for second-line therapies are required. Regulation of DNA transcription is crucial for tumour progression, metastasis and chemoresistance which offers potential for novel drug targets.

Methods We have reviewed the existing literature on the role of histone deacetylases, nuclear enzymes regulating gene transcription.

Results and conclusion Analysis of available data suggests that a signifant proportion of drug resistance stems from abberant gene expression, therefore HDAC inhibitors
\end{abstract}

Dmitri Pchejetski

d.pshezhetskiy@uea.ac.uk

Aun Muhammad

aun.muhammad08@imperial.ac.uk

1 School of Medicine, University of East Anglia, Bob Champion Research and Education Bldg 2.53, Norwich, UK

2 Department of Surgery and Cancer, Hammersmith Hospital, Imperial College London, 1st Floor ICTEM, Du Cane Road, London W12 0NN, UK

3 University of Malta Medical School, Malta, Malta

4 Faculty of Pharmacy and Medical Sciences, University of Petra, Amman, Jordan

5 Department of Imaging, St Mary's Hospital, London, UK are amongst the most promising therapeutic targets for cancer treatment. Together with genetic testing, they may have a potential to serve as base for patient-adapted therapies.

Keywords HDACS - Platinum resistance - Ovarian cancer $\cdot$ Platinum $\cdot$ Chemotherapy $\cdot$ Molecular targeting

\section{Overview of ovarian cancer}

Ovarian cancer is the leading cause of death arising from gynaecological malignancies and the fourth most common form of cancer in women in developed countries, after breast, lung, and colorectal cancer (Permuth-Wey and Sellers 2009; Gayther and Pharoah 2010). Around 204,000 new cases of ovarian cancer are diagnosed worldwide yearly with the highest incidence being in the USA and Northern Europe (RauhHain et al. 2011). The disease is prevalent in older, postmenopausal women and over $80 \%$ of cases are diagnosed in women over 50 years of age (Herzog and Pothuri 2006). The main risk factors associated with ovarian cancer are family history, infertility, and increasing age (Tortolero-Luna and Mitchell 1995; Cetin et al. 2008). The estimated risk of developing ovarian cancer in monozygotic twin of an affected patient is twice the non-twin sibling risk, implies that familial risk of ovarian cancer may be more related to genetic factors than to shared environmental effects (Gayther et al. 2007). Further, positive correlations were observed with dietary consumption of fats and proteins (Bosetti et al. 2001).

Initial symptoms of ovarian cancer prior to diagnosis are non-specific and include vaginal bleeding, gastrointestinal discomfort, and urinary tract symptoms (Friedlander 1998). Further, over $95 \%$ of epithelial ovarian cancer patients experience abdominal complaints for many months prior to their diagnosis (Goff et al. 2007; Lowe et al. 2009). The initial 
Table 1 Ovarian cancer FIGO classification

\begin{tabular}{ll}
\hline Stage & Description \\
\hline I & Ovarian cancer limited to one or both ovaries \\
II & Cancer spread outside the ovary or ovaries, but it is inside the pelvis \\
III & $\begin{array}{c}\text { Cancer has grown outside the pelvis into the abdominal cavity or involvement of upper abdominal, } \\
\text { inguinal or retroperitoneal lymph nodes }\end{array}$ \\
IV & Cancer has spread into other body organs such as the liver or outside the peritoneal cavity \\
\hline
\end{tabular}

According to the International Federation of Gynecology and Obstetrics (FIGO) staging system, ovarian cancer is categorised into four surgical stages (described above). These stages outline treatment options, and a higher stage is associated with a worse prognosis. Adapted from (Benedet et al. 2000) diagnostic workup includes a pelvic examination, ultrasound examination, computed tomography scans, and a blood test for cancer antigen 125 (CA 125), yet none of these techniques can be reliably used for early detection. CA-125 is a tumour marker produced by ovarian cancer cells that is detectable in the serum of $>80 \%$ of women with ovarian carcinomas (Klug et al. 1984). However, it is raised in a number of benign ovarian disorders as well as pregnancy, rendering it mostly useful for monitoring treatment response or disease recurrence (Tuxen et al. 1995; Marsden et al. 2000; Meyer and Rustin 2000). Ovarian cancer has four surgical stages according to the International Federation of Gynecology and Obstetrics (FIGO) staging system (Table 1), which outlines patient prognosis and treatment (Bast et al. 2009).

Ovarian cancer is broadly classified into three cellular and histological subtypes. The cellular classification comprises epithelial tumours, germ cell (ova) tumours and the sex cord (stromal) tumours (Kurian et al. 2005). Histologically, each ovary is covered with germinal epithelium cells beneath which are two regions; an outer cortex and inner medulla responsible for oogenesis and neurovascular support, respectively (Naora and Montell 2005). Every histological subtype of ovarian cancer has different molecular genetic changes underlying its progression. Epithelial ovarian cancer is the most common type of malignant ovarian tumour, occurring in $90 \%$ of cases. Epithelial ovarian cancer is morphologically divided into four distinct subtypes; serous is the most malignant tumour of the epithelial ovarian cancer followed by endometrioid, clear cell and mucinous (Bowtell 2010). This review presents an overview of epithelial ovarian cancer, drug resistance and relapse and a particular focus on the role of histone deacetylase inhibitors as novel drugs in the field.

\section{Biology of epithelial ovarian cancer}

Most ovarian cancers arise from the surface epithelium (Piek et al. 2004) yet the biological mechanism behind this transformation is not precisely understood. The theory of incessant ovulation attributes repeated disruption of the ovarian epithelium that leads to malignant transformation of the epithelial cells (Fathalla 1971; Booth et al. 1989). Factors that suppress incessant ovulation include pregnancy and use of contraceptive that are associated with reduced risk of developing ovarian cancer. Hormones including gonadotropins and sex steroids are thought to influence tumorigenesis. Excessive gonadotropin secretion during menopause may increase the risk of malignant alterations in the ovaries by stimulating the growth of ovarian epithelial cells (Risch 1998). It is debatable whether high androgen levels may increase risk of ovarian cancer. While it has been shown that $90 \%$ of ovarian cancer tissue were positive for the androgen receptor (Wang and Chang 2004) a case-controlled study showed no association between serum levels of androgens and ovarian cancer risk (Rinaldi et al. 2007).

Ovarian cancer development involves the accumulation of several genetic alterations that, respectively, activate or silence oncogenes and tumour suppressor genes (Gayther et al. 1997; Schuijer and Berns 2003). Inherited ovarian cancer comprises 5-15\% of ovarian cancer (Boyd 1998). It is associated with improved overall survival and better clinical outcome than sporadic cancer. This may be due to an earlier diagnosis and subsequent earlier treatment. The BRCA1 and BRCA2 tumour suppressor genes are the most important predisposition genes for ovarian cancer and account for about $90 \%$ of ovarian cancers in the hereditary breast and ovarian cancer syndrome (Gayther et al. 1997; Stratton et al. 1997). BRCA1 and BRCA2 are key proteins that mediate DNA double-strand break repair (D'Andrea and Grompe 2003). Germ line mutations in the DNA mismatch repair (MMR) genes (hMLH1, hMSH2, hMSH6, PMS1, PMS2) which are commonly associated with non-polyposis colorectal cancer (HNPCC) are also associated with ovarian cancer. Ovarian cancer risk in HNPCC families is more than $12 \%$ (Prat et al. 2005). The genes associated with familial ovarian cancer are also involved in disease pathogenesis of the more prevalent sporadic ovarian cancer.

A mutation of the p53 gene is the most common genetic alteration in epithelial ovarian cancers. This tumour suppressor gene encodes a transcription factor that has a role in regulating cell cycle progression, DNA repair, and cell 
death. The majority of early and advanced stage serous carcinomas have mutant p53 (Havrilesky et al. 2003; Leitao et al. 2004; Palmer et al. 2008). PTEN tumour suppressor (phosphatase and tensin homolog) is one of the mutated tumour suppressor genes in ovarian cancer and has a role in cell apoptosis, proliferation and migration (Kolasa et al. 2006; Goff et al. 2007). The RAS family consists of three functional genes, Hras, K-ras, and N-ras that are involved in signal transduction. The K-ras mutation is a common feature in ovarian mucinous carcinomas (Auner et al. 2009). The combination of activating mutations in the oncogenic K-ras gene and PTEN deletion plays a role in the development of endometrioid epithelial ovarian cancer (Dinulescu et al. 2005). The c-MYC proto-oncogene, which participates in the regulation of cellular proliferation, apoptosis and cell differentiation, has also been shown to be overexpressed in endometrioid and clear cell carcinomas (Plisiecka-Halasa et al. 2003). Genes related to the WNT/b-catenin and cadherin signalling pathways were overexpressed in high-grade serous tumours, including $\mathrm{N}$-cadherin and P-cadherin (Tothill et al. 2008). Such data show that each subtype of ovarian cancer has distinct gene mutations. Gene expression analyses can distinguish histological subtypes based on their global gene expression profiles (Cho and Shih Ie 2009; Gomez-Raposo et al. 2010).

\section{Treatment of ovarian cancer}

Treatment of ovarian cancer broadly encompasses surgery, radiotherapy and chemotherapy. Treatment depends upon various parameters such as stage, the histopathologic type, patient's age, patient's desire to have children and overall health status (Cannistra 2004; Marcus et al. 2014). Surgery prior to chemotherapy depends on the size of the tumour and the patient condition. Platinum-based chemotherapy has been used to reduce the size of the tumour before surgery. While neoadjuvant chemotherapy makes surgical operation easier, surgical reduction of tumour bulk prior to chemotherapy might reduce the chance of developing chemo-resistance (Morrison et al. 2007). Radiotherapy can be used to treat residual cancer after cytoreductive surgery and chemotherapy (Bese et al. 2009). The size and the site of residual disease and tumour grade determine the successful outcome (Dembo 1983; Einhorn et al. 2003). Radiotherapy could enhance survival rate when combined with surgery and chemotherapy (Einhorn et al. 1999).

Neoadjuvant or adjuvant chemotherapy is administered to most ovarian cancer patients. Chemotherapy drugs are categorised into several groups based on their chemical structure and mechanism of action (Table 2). Platinumbased agents are the first-line choice drugs. The standard treatment for ovarian cancer patients is combination therapy using carboplatin and paclitaxel due to its effectiveness and favourable toxicity profile (Ozols et al. 2003). Chemotherapy can be administered via the oral, intravenous or intraperitoneal (IP) with the latter showing an improved progression-free survival (Markman 2001; Armstrong and Brady 2006). The side effects of IP therapy can be severe such as the toxicity, catheter-related problems, abdominal pain, bloating, fatigue, infection and gastrointestinal disturbance (Walker et al. 2006; Fung-Kee-Fung et al. 2007).

Platinum-based therapy is very effective in the treatment of ovarian cancer. However, patients frequently develop platinum resistance. Resistance can be either acquired, when the patients respond to the chemotherapy but then develop resistance afterwards or intrinsic, when the patients are unaffected by platinum treatment at first exposure (refractory). Drug resistance is a multi-factorial phenomenon involving various mechanisms. These can be due to decreased platinum uptake or increased platinum-DNA adduct repair and damage tolerance. Further, cellular glutathione or metallothionein cause increased efflux of cisplatin. Alternatively, there could be alterations in the signalling pathways affecting apoptosis (Kartalou and Essigmann 2001; Wernyj and Morin 2004; Ohmichi et al. 2005).

At present there are a number of drugs that are emerging as potential therapeutics in ovarian cancer. Sorafenib is a receptor tyrosine kinase inhibitor. It inhibits protein kinases such as vascular endothelial growth factor receptor

Table 2 Cytotoxic chemotherapy groups active in ovarian cancer and their mechanism of action (Dunton 1997; Piccart et al. 2001)

\begin{tabular}{ll}
\hline Group & Action and example \\
\hline $\begin{array}{l}\text { Anti-metabolite drugs } \\
\begin{array}{l}\text { Anti-tumour antibiotics including } \\
\text { topoisomerase II }\end{array}\end{array}$ & $\begin{array}{l}\text { These interfere with DNA and RNA synthesis e.g., 5-fluorouracil } \\
\text { These inhibit DNA and RNA synthesis leading to cell death such as doxorubicin }\end{array}$ \\
$\begin{array}{l}\text { Plant-based compounds } \\
\begin{array}{l}\text { Alkylating agents } \\
\text { Platinum-based agents }\end{array}\end{array}$ & $\begin{array}{c}\text { These are natural products of plant alkaloids that can inhibit mitosis or enzymes, thereby } \\
\text { preventing protein synthesis necessary for cell like etoposide and taxanes }\end{array}$ \\
$\begin{array}{l}\text { These interfere with DNA thus prevent the cancer cells growth } \\
\text { are the most effective chemotherapy for ovarian cancer on whole, showing high response } \\
\text { rates and long survival for advanced ovarian cancer patients such as cisplatin and } \\
\text { carboplatin }\end{array}$
\end{tabular}


(VEGFR) and platelet-derived growth factor receptor (PDGFR) together with rat sarcoma proto-oncogene (RAS), rat fibrosarcoma protein kinase (RAF) and mitogen-activated protein kinase (MAPK) (Matei et al. 2011; Zhang et al. 2013). The expression of histone deacetylases (HDACs) is increased in cells undergoing epithelialmesenchymal transformation; however, the expression of HDACs was not increased in the presences of sorafenib. This suggests that sorafenib may block the expression of HDACs (Zhang et al. 2013). Some ovarian cancer patients on sorafenib experienced stable disease for up to 1 year in a phase II trial (Strumberg et al. 2005). In a phase III trial, patients with ERK and b-RAF positive tumours had neoadjuvant sorafenib at a dose of $800 \mathrm{mg}$ daily. $24 \%$ had a 6 month progression-free survival (Matei et al. 2011). So far sorafenib trials have targeted patients with advance ovarian cancer and trials were not well-standardised; thus, its role in ovarian cancer has yet to be defined (Smolle et al. 2014)

Angiogenesis is a critical step in ovarian cancer metastasis; thus, anti-angiogenic drugs that target VEGF and PDGF have a role to play in ovarian cancer treatment (Conteduca et al. 2014). Bevacizumab, an anti-VEGF monoclonal antibody, has been tried as a single agent and in combination with platinum-based chemotherapy in recurrent or metastatic epithelial ovarian cancer (Burger et al. 2007; Kudoh et al. 2011; Sorbe et al. 2012). The treatment regimens are generally well tolerated and emerging results suggest improved patient efficacy (McGonigle et al. 2011; Gavalas et al. 2013). A phase III trial showed that bevacizumab improved chemotherapy efficacy and progressionfree survival in initial disease management (Burger et al. 2011; Perren et al. 2011). Similar outcomes were obtained in platinum-sensitive ovarian cancer (Aghajanian et al. 2012). Aflibercept is a fusion protein of VEGFR 1 and VEGFR2 attached to the Fc portion of human IgG. The safety profile of the drug in combination with docetaxel is established. Preliminary results are promising and warrant further investigation (Coleman et al. 2011). A number of other anti-angiogenic drugs have undergone pre-clinical studies (Wedge et al. 2005; Bauerschlag et al. 2010; Karlan et al. 2012). Despite their efficacy, patients can develop drug resistance that may be due to cancer cell utilisation of alternative angiogenic pathways and recruitment of vascular progenitor cells (Conteduca et al. 2014).

One mechanism that underlies ovarian tumour progression, metastasis and chemoresistance is transcriptional regulation. TATA-box binding protein-associated factors (TAFs) regulate dedifferentiated states in ovarian cancer (Ribeiro et al. 2014). Understanding the nuclear mechanisms associated with treatment failure in ovarian cancer would uncover novel pharmacologic targets to treat patients.

\section{Histone deacetylase (HDACS)}

\section{The biological function of histone deacetylases (HDACs)}

Transcription in eukaryotic cells is influenced by the manner in which DNA is packaged. DNA is packaged into chromatin, a highly organised protein DNA complex. The basic units of the chromatin are nucleosomes. It is comprised of four histones; two H2A, H2B dimmers and H3, $\mathrm{H} 4$ tetramer. The presence of acetylated lysine residues in histone tails is associated with a more relaxed chromatin state and gene-transcription activation, while the deacetylation of lysine residues is associated with a more condensed chromatin state and transcriptional gene silencing (Fig. 1) (Strahl and Allis 2000). Thus, the balance between histone acetyltransferase (HAT) and histone deacetylase (HDAC) activities play a crucial role in chromatin remodelling and

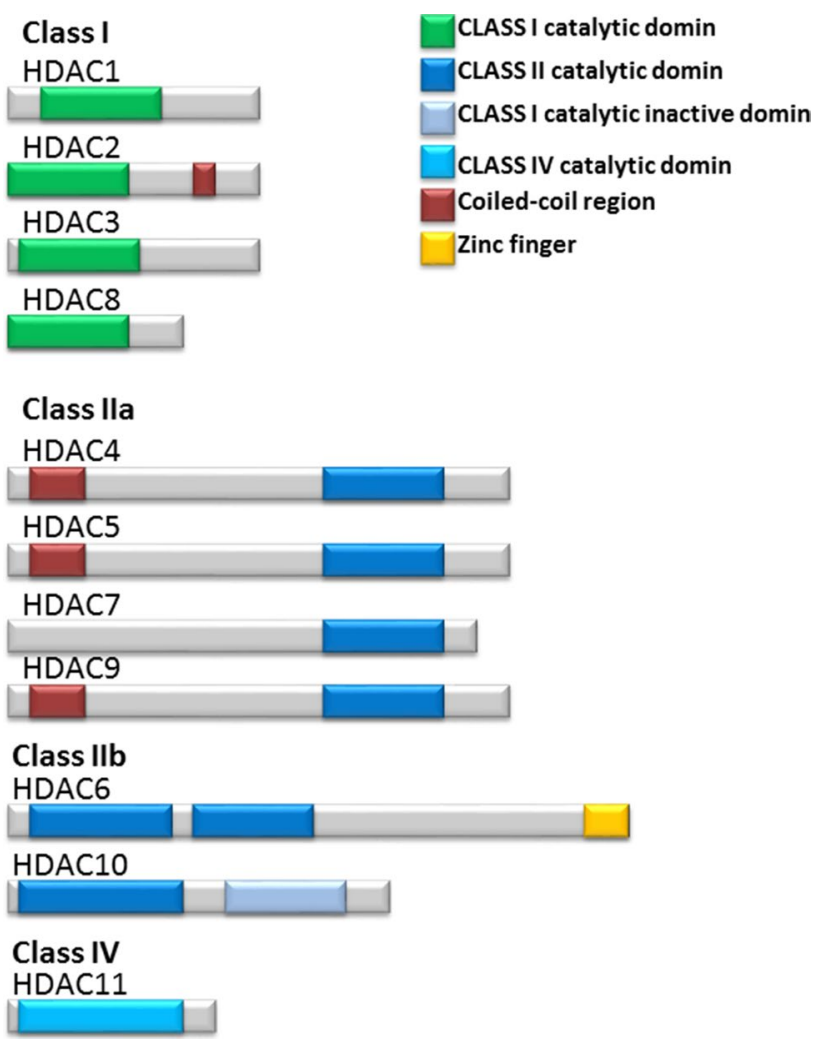

Fig. 1 Histone acetylation/deacetylation regulates transcription. The balance between the acetylated and deacetylated states of histones is mediated by two different sets of enzymes: histone acetyltransferases (HATs) and histone deacetylases (HDACs). Acetylation of the histone tails is associated with an open chromatin structure and active transcription. Conversely, removing the acetyl groups on the histone tails by HDAC enzyme activity is associated with condensed chromatin structure and transcriptional repression. Adapted from Marks et al. (2001) 


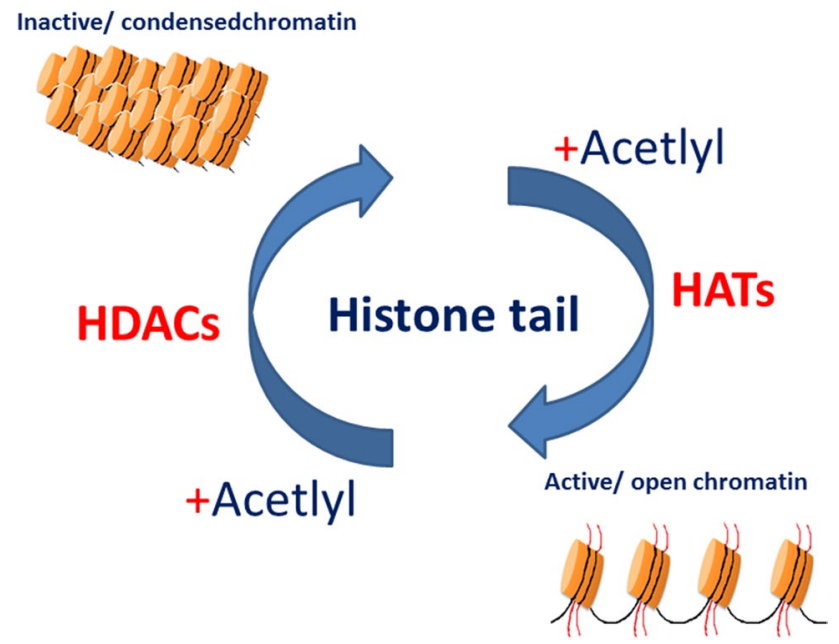

Fig. 2 Schematic representation of class I; HDAC1, 2, 3 and 8, class IIa; HDAC4, 5, 7 and 9, class IIb; HDAC6 and 10 and class IV; HDAC11. HDAC enzymes with the structural and the functional domains included the capacity of the structurally diverse HDAC inhibitors to inhibit the activity of each HDAC classes or specific isoform HDACs are shown. Adapted from Bolden et al. (2006)

in the regulation of gene transcription. HDACs family contained 18 known enzymes.

These HDAC enzymes divided into four classes based on sequence similarity to the yeast (Fig. 2). The class I, II, and IV HDACs are zinc-dependent and class III HDACs (SIRT1-SIRT7) are NAD+ dependent in their enzymatic activity class I HDACs include HDAC1, 2, 3, and 8. They are 400 residues in length and are considered as nuclear proteins; however, HDAC3 has the ability to shuttle between the nucleus and the cytoplasm. Class II HDACs include HDAC4, 5, 6, 7, 9, and 10. These enzymes have the ability to shuttle between the nucleus and cytoplasm. In addition, class II HDACs enzymes are grouped into class IIa (HDAC4, 5, 7, and 9) and IIb (HDAC6 and 10) because class IIa enzymes have $\mathrm{N}$-terminal extension of 600 residues that are thought to have distinctive function, but class IIb enzymes have two catalytic domains. Class IV, share the common properties between class I and class II HDACs and includes HDAC11 as reviewed in (Verdin et al. 2003). Class I enzymes are ubiquitously expressed in humans, whereas class II enzymes show tissue specific expression. Three of the class IIa HDACs, HDAC4, 5 and 9, show highest expression in heart, skeletal muscle and brain. The highest expression of HDAC7 is in heart and lung tissues. HDAC6 is predominantly expressed in testis, while HDAC10 is expressed in liver, spleen and kidney (Verdin et al. 2003). The HDACs are not redundant in their biological activity. Knockout mouse experiments demonstrated a different function for each HDAC. The class I genes HDAC1 or HDAC2 knockout in mice resulted in embryonic or perinatal lethality, respectively. However, class II HDAC knockout mice were viable and fertile, but all display developmental abnormalities. HDAC7 null mouse embryos have defects in blood vessel development and integrity. HDAC9 null mice display defects in cardiac muscle development, reviewed in (Lane and Chabner 2009).

Both class I and class II HDACs act on histone substrates and on non-histone proteins which play important roles in the regulation of various cellular processes. HDAC 1 has been reported to affect the deacetylation of the transcription factor p53, while HDAC6 deacetylate $\alpha$-tubulin and heat-shock protein 90 (HSP90) (Bolden et al. 2006). HDAC enzymes exist in multi-protein complexes and recruited to certain promoters by interaction with specific transcription factors although these enzymes are unable to bind directly to DNA. For example, HDAC1 and HDAC2 are thought to be found together in multi-protein complexes, and a number of transcription factors target these two enzymes to specific promoters to suppress transcription (MacDonald and Roskams 2008). Amongst all HDAC enzymes, only HDAC 3 has the ability to interact with class I and II HDACs. HDAC3 interacts with HDAC4, SMRT (silencing mediator for retinoid and thyroid receptors) and $\mathrm{N}-\mathrm{CoR}$ (nuclear receptor co-repressor) complexes to repress transcription. The suppression of HDAC4 binding to SMRT and N-CoR and to HDAC3 lead to a loss of enzymatic activity related to HDAC4. It has been reported that class II HDACs require an enzymatically active SMRT/N-CoRHDAC3 complex to regulate transcription (Grozinger et al. 1999; Fischle et al. 2002) with the exception of HDAC6 which contains an internal dimer including two functional catalytic domains and thus does not require another HDAC enzyme for its activity (Grozinger et al. 1999). HDAC6 has been shown to specifically deacetylate $\alpha$-tubulin at lysine 40. Therefore, this lysine has been used as a marker of microtubule stability (Piperno et al. 1987). Sirt1, a class III HDAC, has been reported to deacetylate the p53 gene and to inhibit the transcriptional activity and apoptosis mediated by this gene (Cheng et al. 2003). Class II HDACs can deacetylate the four core histones and act like transcriptional corepressors. These enzymes either act through transcriptional corepressors or bind directly to sequencespecific transcription factors, such as myocyte enhancer factor-2 (MEF2). The MEF2 family of transcription factors is one of the important targets of class IIa HDACs. MEF2, major transcriptional activators for the expression of muscle-specific genes, also regulate other cellular programs, including neuronal survival, $\mathrm{T}$ cell apoptosis, and growth factor responsiveness. When class IIa HDACs bind to MEF2, it change MEF2 from being transcriptional activators into repressors. The MEF2-binding site is conserved amongst all four class IIa HDACs enzymes (Gregoire and Yang 2005). 
The homodimeric and heterodimeric interactions of HDAC might indicate that these interactions are important for the regulation of HDAC activity. Histones not only undergo acetylation and deacetylation but undergo different post-translational modifications such as; phosphorylation, methylation, ubiquitination and sumoylation which are thought to influence the chromatin structure, DNA accessibility and gene expression regulation (Struhl 1998).

\section{The role of HDACs in cancer}

The role of individual histone deacetylases (HDACs) in the regulation of cancer cell proliferation was investigated using siRNA-mediated knockdown (HDAC1, HDAC2, HDAC3, HDAC4 and HDAC7) in HeLa cells. Proliferation analysis showed that knockdown of HDAC1 and HDAC3 resulted in slower cell growth compared with HDAC4 and HDAC7 and that only HDAC1 and HDAC3 are important in cellular proliferation (Glaser et al. 2003). Another study showed that siRNA knockdown of HDAC2 can arrest the cell cycle either at the G(1) phase or during G(2)/M transition, resulting in the loss of mitotic cells and cell growth inhibition. In contrast, HDAC2 knockdown showed no effect on cell proliferation (Senese et al. 2007). Furthermore, HDACs 1 and 2 share a high degree of homology and coexist within the same protein complexes. In spite of their close association, each possesses unique functions. High expression of HDAC2 has been seen in colorectal cancer at polyp stage (more than HDAC1 expression), suggesting that HDAC2 might be involved in the early events of cancer development (Huang et al. 2005). The up-regulation of HDAC3 protein expression has been reported in human colon tumours and knocking down of HDAC3 expression by RNA interference in colon cancer cell lines resulted in growth inhibition, a decrease in cell survival and increased apoptosis. Similar effects were observed for HDAC2 and, to a lesser extent, for HDAC1 (Wilson et al. 2006). HDAC8 has been implicated in smooth muscle cell contractility (Waltregny et al. 2005) although its knockdown by RNA interference inhibits growth of human lung, colon, and cervical cancer cell lines (Vannini et al. 2004). This shows that class I HDACs are essential for cell cycle regulation, proliferation and survival with the exception of HDAC2 which is involved in the regulation of apoptosis in tumour cells. Altered expression of certain HDACs has been reported in tumours compared with normal cells. Increased expression of HDAC1 has been found in gastric cancers, oesophageal squamous cell carcinoma, hormone-refractory prostate cancer, and colon cancer (Choi et al. 2001; Wilson et al. 2006). HDAC2 expression is increased in human colon cancer (Zhu et al. 2004). HDAC3 expression is increased in human tumour samples of colon cancer compared with normal tissue (Shebzukhov et al. 2005). HDAC5 is down-regulated in colon cancer (Scanlan et al. 2002). Class I HDACs have been shown to be expressed at significantly higher levels in ovarian cancers in comparison with normal ovarian tissues, with no significant difference in Class II HDAC expression between the two groups (Khabele et al. 2007). Furthermore, the high expression of class 1 HDACs (HDAC1, 2, and 3) has been associated with poor prognosis in endometrioid subtypes of ovarian and endometrial carcinomas (Weichert et al. 2008). In addition, the expression levels were considerably different in specific tumour histological subtypes with mucinous carcinomas showing the highest positivity rates $(71 \%)$; followed by high-grade serous $(64 \%)$, clear cell $(54 \%)$ and endometrioid subtypes (36\%). HDAC class I expression was generally higher in strongly proliferating tumours (Khabele et al. 2007; Weichert et al. 2008). A recent study using 115 ovarian tumour tissues confirmed that expression of nuclear HDAC1, HDAC2 and HDAC3 proteins increased stepwise in benign, borderline and malignant tumours. Analysis of the effect of specific isoforms of HDACs using siRNA against HDAC1, HDAC2 and HDAC3 on the ovarian carcinoma cell lines, SKOV3, OVCAR3, IGROV-1, ES-2, TOV112D, A2780 and A2780/ CDDP showed that knockdown of HDAC1 considerably reduced the proliferation of ovarian carcinoma cells, while knockdown of HDAC3 reduced cell migration (Hayashi et al. 2010). This indicates that HDAC enzymes especially class I have important roles in ovarian carcinogenesis which provides a rationale for targeted inhibition of HDAC enzyme in the treatment of ovarian cancer.

\section{Therapeutic implications of HDAC inhibitors}

HDAC inhibitors are amongst the most promising therapeutic targets for cancer treatment due to their critical role in the regulation of transcription of key genes controlling important cellular functions such as cell proliferation, cell cycle regulation and apoptosis (Spiegel et al. 2012). The balance between histone acetylation and deacetylation is required for active gene expression (Secrist et al. 2003). The catalytic domain of HDAC is closely conserved from bacteria to humans, and the knowledge of its crystal structure has helped in the development of potent HDAC inhibitors (HDACi) based on the molecular mode of action of HDAC. HDAC inhibitor usually consist of a metal-binding moiety that binds the catalytic metal atom within the HDAC active site and a capping group that interacts with the residues at the entrance of the active site (Marks et al. 2001). A linker correctly positions the metal-binding moiety and capping group for interactions in the active site. Crystallographic studies have revealed that SAHA (suberoylanilide hydroxamic acid or vorinostat) inhibits HDAC activity by binding to the active site of the enzyme (Finnin et al. 1999; Marks et al. 2001). A number of natural and 
synthetic compounds have been shown to be able to inhibit the activity of class I, II, and IV HDACs. HDACi can be divided into several classes: hydroxamic acids, e.g., trichostatin A (TSA) and suberoyl anilide bishydroxamic acid (SAHA), short-chain fatty acids, e.g., sodium butyrate $(\mathrm{NaB})$, cyclic tetrapeptides (e.g., traposin), and benzamides (e.g., MS-275) (Villar-Garea and Esteller 2004). The efficacy of HDAC inhibitors as anticancer agents has been demonstrated in a wide range of haematological and solid tumour cell lines and in experimental animal models (Saito et al. 1999; Drummond et al. 2005).

HDAC inhibitors exhibit the anticancer effects through regulation of gene expression by histone acetylation and through increasing acetylation of other cellular proteins. The molecular pathways that trigger cell death by HDAC inhibitor in ovarian cancer are not fully understood. But there are a number of genes identified to be either up or down-regulated following HDACi treatment. These genes involved in a variety of cellular processes and networks such as those involving the proapoptotic proteins; Fas, Fas ligand, Bak, Bax, Bim, BLxl, Bcl2, Caspase 3, and the cell cycle regulation proteins such as p21 and p27 (Drummond et al. 2005). HDACi treatment has been reported to activate caspase-9, caspase-3, and caspase- 8 and inhibit anti-apoptotic Bcl-2 family members (Bcl-2 and Bcl-XL) in breast, colon, hematopoietic, lung, melanoma, ovarian, prostatic, renal, and stomach cancer cell lines using a novel hydroxamate-based HDACI, CG0006 (Hwang et al. 2009). BcL2 proteins control the intrinsic pathway of apoptosis at the mitochondria by preventing the release of the cytochrome c. Therefore, the inhibition of Bcl-2 and Bcl-XL by HDACi treatment promotes the release of cytochrome c followed by caspase- 9 and caspase- 3 activation leading to apoptosis. As discussed previously, the expression of $\mathrm{Bcl} 2$ has been shown to protect ovarian cancer cells from the toxic effect of cisplatin (Hwang et al. 2009). Thus, HDACi could play role in cisplatin resistance in ovarian cancer by modifying the expression of the genes could confer resistance to cisplatin. It has been shown that HDACi treatment induced the accumulation of both proteins p21 and p27, which express in low level in untreated ovarian cancer cell lines and have important role in cell cycle regulation (Hwang et al. 2009). Moreover, specific knockdown by siRNA against HDAC4 in ovarian carcinoma IGROV-1 induced the expression of p21 (Mottet et al. 2009). The up-regulated p21 and p27 bind to cyclin-CDK complexes to inhibit their catalytic activity and induce cell cycle arrest in cancer cells. The study showed that over-expression of P21 and p27 correlates with increased apoptosis, demonstrating that p21 and p27 levels might be essential for HDACi-induced apoptosis (Abukhdeir and Park 2008). This is just one of the possible pathways that HDACi utilise to arrest cancer cell growth. It has also been demonstrated that histone deacetylase inhibitors exhibit anti-cancer activity and induces apoptosis in ovarian cancer cells via up-regulation of E-cadherin expression and accumulation of acetylated histones $\mathrm{H} 3$ and $\mathrm{H} 4$. The study examined the effect of HDACi (SAHA, VPA, TSA, and $\mathrm{NaB}$ ) using human ovarian cancer cell lines (SKOV3, OVCAR-3, TOV-21G, OV-90, TOV-112D, OVCA420, OVCA429, OVCA432, and OVCA433) (Takai et al. 2004).

Hayashi et al. (2010) has reported that knockdown of HDAC 3 by siRNA reduced the cell migration with elevated E-cadherin expression in ovarian cancer cells. E-cadherin is one of the important molecules for adhesion between adjacent epithelial cells. When the ovarian epithelial cell undergoes transformation, the cell can detach from the original basement membrane and metastasize throughout the peritoneal cavity. E-cadherin is membrane glycoproteins that mediate adhesion between cells which is an important event in metastasis. Loss of E-cadherin has been associated with ovarian cancer metastasis (Sawada et al. 2008). E-cadherin might have tumour suppressor function in ovarian carcinoma because it has been reported to be silenced by DNA hypermethylation in human breast and prostate carcinomas (Graff et al. 1995). The up-regulated E-cadherin after HDACi treatment in ovarian carcinoma cells indicate that this gene also involved in HDACi meditating cell death in ovarian cancer (Takai and Narahara 2007).

The generation of reactive oxygen species (ROS) is another phenomenon observed in HDAC inhibitor-treated cells. It has been reported that HDAC inhibitors; TSA, MS-275, FK228 and HC toxin promote the induction of DNA damage by a variety of anticancer agents; doxorubicin, paclitaxel, etoposide, cisplatin, bleomycin, mitomycin-C and topotecan, which resulted in enhanced generation of ROS, then cell death in human ovarian cancer cell lines; OVCAR-3, OVCAR-4, OVCAR-5, OVCAR-8, SKOV-3, and TYK-nu (Ozaki et al. 2008). This showed that increased generation of ROS play a role in HDAC-mediated cell death. It seems that HDACi-induced cell death is through extrinsic apoptotic pathway, which involves the cross-linking of certain death-inducing receptors like Fas by their legends (Drummond et al. 2005) and consequent activation of caspases 3,8 and 9. In addition to this, HDACi utilises the intrinsic apoptotic pathway through the disruption of outer mitochondrial membrane integrity and later release of cytochrome $\mathrm{c}$ and other pro-apoptotic molecules. The involvement of these factors and pathways in the anti-cancer activity of HDACi need to be investigated. In addition, the effects of HDACi can be cell-type-dependent, and different HDACi can have different effects in the same cell type as shown by (Ozaki et al. 2008). This possibly relates to the HDAC-specificity profiles of the different compounds and HDACs profile in different cell lines since different HDAC isoforms contribute selectively to the development of ovarian cancer. 


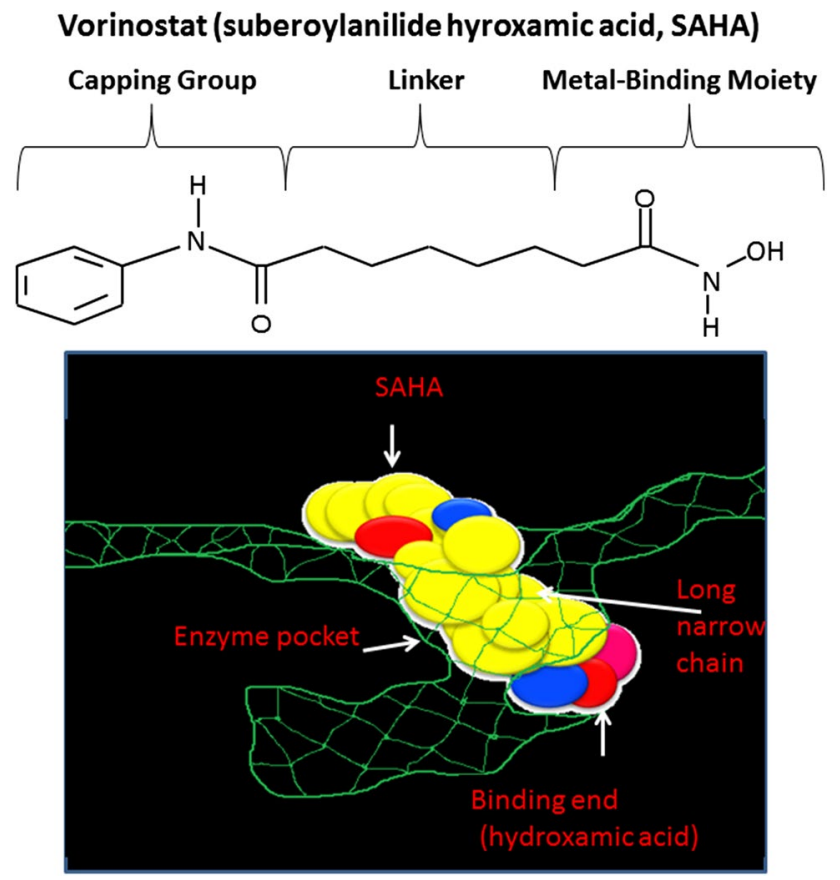

Fig. 3 Vorinostat inhibits HDAC activity by binding to the pocket of the catalytic site. The hydroxamic acid moiety of vorinostat binds to a zinc atom (pink); this allows the rest of the molecule to lie along the surface of the HDLP protein. Adapted from Marks et al. (2001)

Another type of HDACi is sphingosine-1-phosphate (S1P). S1P is a lipid mediator that can act intracellularly as an HDAC inhibitor (Hait et al. 2009). S1P regulates histone acetylation by binding to HDAC1 and HDAC2. As S1P directly inhibits HDACs, it plays an essential role in epigenetic regulation of nuclear expression. S1P is aberrantly expressed in ovarian cancer and regulates key processes involved in ovarian cancer initiation and progression. Molecular agents that block S1P mediated signalling induce cellular apoptosis or inhibit ovarian cancer cell proliferation. Such evidence highlights a potential role for S1P as a drug target in ovarian cancer (Dai et al. 2014).

SAHA has been approved by the US Food and Drug Administration for the treatment of cutaneous T-cell lymphoma (CTCL), a form of non-Hodgkin's lymphoma. Romidepsin is the second HDAC inhibitor to be approved by the FDA for the treatment of CTCL. Romidepsin has a very different chemical structure compared to vorinostat (Fig. 3). Romidepsin is a selective inhibitor for class I HDACs, whereas vorinostat is a pan-HDAC inhibitor (Campas-Moya 2009). Most HDACi are not specific to subclasses of HDAC enzymes. They inhibit many of the known mammalian HDACs. There has been increased attention over the past several years to create selective HDAC inhibitor. Given that specific HDAC isoform has specific function in cancer, selective HDAC inhibitors will be very useful in cancer treatment. This led to several class-selective and some isoform-selective inhibitors such as MS-275. MS-275 is more active against HDAC1 than against HDAC3 $(\mathrm{Hu}$ et al. 2003). Depsipeptide is more potent against HDAC1 and HDAC2 than against HDAC4 and HDAC6 (Furumai et al. 2002). 2f-MC1568 and 4a-MC1511 HDAC inhibitors are derivative of aroyl-pyrrolyl-hydroxyamides (APHAs) 2f-MC1568 was selective to class II but with poor inhibitory activity; however, 4a-MC1511 showed effective inhibitory activity against class II and to less extent to class I (Mai et al. 2005). Therefore, further studies are necessary in order to create HDAC isoform specific inhibitors.

The effect of HDACi in the treatment of epithelial ovarian cancer has been reported by Takai et al. (2006). The study investigated the effect of scriptaid, a member of the hydroxamic class of HDAC inhibitors that is selective for class I HDACs on Ishikawa endometrial cancer cell line, SKOV-3 ovarian cancer cell line, and normal human endometrial epithelial cells. The data showed that Scriptaid induced growth inhibition and increased acetylation of $\mathrm{H} 3$ and $\mathrm{H} 4$ histone for both endometrial and ovarian cancer cell lines. While normal endometrial epithelial cells were viable following treatment with similar doses of Scriptaid. The study showed the effectiveness of HDACi in mediating tumour cell selective killing compared with the normal cell. This may be because cancer cells have several genetic defects and, unlike normal cells, are unable to reverse the adverse effects of HDAC inhibitors. Vorinostat has been reported to induce cell death and increase caspase- 3 activity in three ovarian cancer cell lines (OVCAR-3, SK-OV3 , and A2780) and in primary ovarian cancer cells isolated from malignant ascites collected from five patients with stage III ovarian carcinomas.

Furthermore, 2780AD, a doxorubicin-resistant ovarian cancer cell line cells were responsive to vorinostat (Sonnemann et al. 2006). Pre-treatment with vorinostat and trichostatin A (TSA) has been shown to enhance the cytotoxicity of DNA-targeting agents such as VP-16, ellipticine, doxorubicin, and cisplatin but not that of drugs which do not target the DNA, like the antimetabolite 5-fluorouracil (Kim et al. 2003). In addition, valproic acid (2-propylpentanoic acid; VPA), an HDAC inhibitor that inhibits both class I and II HDACs, has been reported to have synergistic cytotoxicity with cisplatin in human ovarian carcinoma cells (SK-OV-3, OVCAR-3, TOV-21G, A2780 and A2780/ CP70) and can restore platinum sensitivity in the acquired cisplatin-resistance cells (Lin et al. 2008). Pre-clinical in vitro studies on the effect of PXD101, a class I and II HDAC inhibitor showed this HDACi exhibit single-agent antitumour activity on human A2780 ovarian cancer xenografts. This effect improved when combined with carboplatin treatment (Qian et al. 2006).

Clinical trials showed the limited therapeutic of some of HDACi such as TSA and trapoxin because they have poor 
bioavailability and toxic side effects at high doses. Other HDACi are degraded after i.v. administration like sodium butyrate and phenylbutyrate thus requiring high doses to achieve maximum tumour killing (Warrell et al. 1998). It has been shown that vorinostat-treated ovarian cancer cell lines and in primary cancer cells derived from malignant ascites obtained from five patients with stage III ovarian cancer had cytotoxic effect as a single agent (Sonnemann et al. 2006). A phase II trial of vorinostat in platinum-resistant/refractory epithelial ovarian patients showed progression-free survival over 6 months, with few having a partial response. However, vorinostat has toxic effects such as thrombocytopenia, neurologic complaints and pain which limit its effectiveness (Modesitt et al. 2008). This provides an evidence that HDAC inhibitors could have a potential role in the treatment of ovarian cancer, but there is need to develop HDAC inhibitor that has a tolerable side effect and efficient in destroying cancer cells.

\section{Conclusions and future perspectives}

Ovarian cancer comprises a heterogenous group of tumours that are associated with a specific prognosis and drug resistance patterns. At present, there is a growing need for novel therapy to improve overall survival and disease-free survival hence reducing ovarian cancer related mortality. Addressing resistance to chemotherapy should be one of the strategies to target resistance to chemotherapy. As most drug resistance is at the level of gene expression, HDAC inhibitors are amongst the most promising therapeutic targets for cancer treatment due to their critical role in the regulation of transcription of key genes controlling important cellular functions such as cell proliferation, cell cycle regulation and apoptosis (Spiegel et al. 2012). While the preliminary results are promising, robust clinical trials are needed to ascertain whether this treatment offers beneficial clinical outcomes with tolerated side-effect profiles. A number of other drugs that target unique cancer pathways are undergoing trials. Given the complexity of disease management and the vast armamentarium of available drugs, utilising genetic tumour profiles has the potential to stratify patients and help select the best drug regimen that provides a superior benefit to risk ratio for each individual patient.

\section{Compliance with ethical standards}

Conflict of interest All authors declare they have no conflict of interest.

Ethical approval This article does not contain any studies with human participants or animals performed by any of the authors.
Open Access This article is distributed under the terms of the Creative Commons Attribution 4.0 International License (http://creativecommons.org/licenses/by/4.0/), which permits unrestricted use, distribution, and reproduction in any medium, provided you give appropriate credit to the original author(s) and the source, provide a link to the Creative Commons license, and indicate if changes were made.

\section{References}

Abukhdeir AM, Park BH (2008) P21 and p27: roles in carcinogenesis and drug resistance. Expert Rev Mol Med 10:e19

Aghajanian C, Blank SV, Goff BA, Judson PL, Teneriello MG, Husain A, Sovak MA, Yi J, Nycum LR (2012) OCEANS: a randomized, double-blind, placebo-controlled phase III trial of chemotherapy with or without bevacizumab in patients with platinum-sensitive recurrent epithelial ovarian, primary peritoneal, or fallopian tube cancer. J Clin Oncol 30(17):2039-2045

Armstrong DK, Brady MF (2006) Intraperitoneal therapy for ovarian cancer: a treatment ready for prime time. J Clin Oncol 24(28):4531-4533

Auner V, Kriegshauser G, Tong D, Horvat R, Reinthaller A, Mustea A, Zeillinger R (2009) KRAS mutation analysis in ovarian samples using a high sensitivity biochip assay. BMC Cancer 9:111

Bast RC Jr, Hennessy B, Mills GB (2009) The biology of ovarian cancer: new opportunities for translation. Nat Rev Cancer 9(6):415-428

Bauerschlag DO, Schem C, Tiwari S, Egberts JH, Weigel MT, Kalthoff H, Jonat W, Maass N, Meinhold-Heerlein I (2010) Sunitinib (SU11248) inhibits growth of human ovarian cancer in xenografted mice. Anticancer Res 30(9):3355-3360

Benedet JL, Bender H, Jones H 3rd, Ngan HY, Pecorelli S (2000) FIGO staging classifications and clinical practice guidelines in the management of gynecologic cancers. FIGO Committee on Gynecologic Oncology. Int J Gynaecol Obstet 70(2):209-262

Bese NS, Iribas A, Dirican A, Oksuz D, Atkovar G, Ober A (2009) Ovarian ablation by radiation therapy: Is it still an option for the ablation of ovarian function in endocrine responsive premenopausal breast cancer patients? Breast 18(5):304-308

Bolden JE, Peart MJ, Johnstone RW (2006) Anticancer activities of histone deacetylase inhibitors. Nat Rev Drug Discov 5(9):769-784

Booth M, Beral V, Smith P (1989) Risk factors for ovarian cancer: a case-control study. Br J Cancer 60(4):592-598

Bosetti C, Negri E, Franceschi S, Pelucchi C, Talamini R, Montella M, Conti E, La Vecchia C (2001) Diet and ovarian cancer risk: a case-control study in Italy. Int J Cancer 93(6):911-915

Bowtell DD (2010) The genesis and evolution of high-grade serous ovarian cancer. Nat Rev Cancer 10(11):803-808

Boyd J (1998) Molecular genetics of hereditary ovarian cancer. Oncology 12(3):399-406 ; discussion 409-310, 413

Burger RA, Sill MW, Monk BJ, Greer BE, Sorosky JI (2007) Phase II trial of bevacizumab in persistent or recurrent epithelial ovarian cancer or primary peritoneal cancer: a Gynecologic Oncology Group Study. J Clin Oncol 25(33):5165-5171

Burger RA, Brady MF, Bookman MA, Fleming GF, Monk BJ, Huang H, Mannel RS, Homesley HD, Fowler J, Greer BE, Boente M, Birrer MJ, Liang SX (2011) Incorporation of bevacizumab in the primary treatment of ovarian cancer. $\mathrm{N}$ Engl $\mathrm{J}$ Med 365(26):2473-2483

Campas-Moya C (2009) Romidepsin for the treatment of cutaneous T-cell lymphoma. Drugs Today 45(11):787-795 
Cannistra SA (2004) Cancer of the ovary. N Engl J Med 351(24):2519-2529

Cetin I, Cozzi V, Antonazzo P (2008) Infertility as a cancer risk factor-a review. Placenta 29(Suppl B):169-177

Cheng HL, Mostoslavsky R, Saito S, Manis JP, Gu Y, Patel P, Bronson R, Appella E, Alt FW, Chua KF (2003) Developmental defects and p53 hyperacetylation in Sir2 homolog (SIRT1)-deficient mice. Proc Natl Acad Sci USA 100(19):10794-10799

Cho KR, Shih Ie M (2009) Ovarian cancer. Annu Rev Pathol 4:287-313

Choi JH, Kwon HJ, Yoon BI, Kim JH, Han SU, Joo HJ, Kim DY (2001) Expression profile of histone deacetylase 1 in gastric cancer tissues. Jpn J Cancer Res 92(12):1300-1304

Coleman RL, Duska LR, Ramirez PT, Heymach JV, Kamat AA, Modesitt SC, Schmeler KM, Iyer RB, Garcia ME, Miller DL, Jackson EF, Ng CS, Kundra V, Jaffe R, Sood AK (2011) Phase 1-2 study of docetaxel plus aflibercept in patients with recurrent ovarian, primary peritoneal, or fallopian tube cancer. Lancet Oncol 12(12):1109-1117

Conteduca V, Kopf B, Burgio SL, Bianchi E, Amadori D, De Giorgi U (2014) The emerging role of anti-angiogenic therapy in ovarian cancer (Review). Int J Oncol 44(5):1417-1424

Dai L, Xia P, Di W (2014) Sphingosine 1-phosphate: A potential molecular target for ovarian cancer therapy? Cancer Invest 32(3):71-80

Dembo AJ (1983) Radiation therapy in the management of ovarian cancer. Clin Obstet Gynaecol 10(2):261-278

D'Andrea AD, Grompe M (2003) The Fanconi anaemia/BRCA pathway. Nat Rev Cancer 3(1):23-34

Dinulescu DM, Ince TA, Quade BJ, Shafer SA, Crowley D, Jacks T (2005) Role of K-ras and Pten in the development of mouse models of endometriosis and endometrioid ovarian cancer. Nat Med 11(1):63-70

Drummond DC, Noble CO, Kirpotin DB, Guo Z, Scott GK, Benz CC (2005) Clinical development of histone deacetylase inhibitors as anticancer agents. Annu Rev Pharmacol Toxicol 45:495-528

Dunton CJ (1997) New options for the treatment of advanced ovarian cancer. Semin Oncol 24(1 Suppl 5):S5-2-S5-11

Einhorn N, Lundell M, Nilsson B, Ragnarsson-Olding B, Sjovall K (1999) Is there place for radiotherapy in the treatment of advanced ovarian cancer? Radiother Oncol 53(3):213-218

Einhorn N, Trope C, Ridderheim M, Boman K, Sorbe B, CavallinStahl E (2003) A systematic overview of radiation therapy effects in ovarian cancer. Acta Oncol 42(5-6):562-566

Fathalla MF (1971) Incessant ovulation-A factor in ovarian neoplasia? Lancet 2(7716): 163

Finnin MS, Donigian JR, Cohen A, Richon VM, Rifkind RA, Marks PA, Breslow R, Pavletich NP (1999) Structures of a histone deacetylase homologue bound to the TSA and SAHA inhibitors. Nature 401(6749):188-193

Fischle W, Dequiedt F, Hendzel MJ, Guenther MG, Lazar MA, Voelter W, Verdin E (2002) Enzymatic activity associated with class II HDACs is dependent on a multiprotein complex containing HDAC3 and SMRT/N-CoR. Mol Cell 9(1):45-57

Friedlander ML (1998) Prognostic factors in ovarian cancer. Semin Oncol 25(3):305-314

Fung-Kee-Fung M, Provencher D, Rosen B, Hoskins P, Rambout L, Oliver T, Gotlieb W, Covens A (2007) Intraperitoneal chemotherapy for patients with advanced ovarian cancer: a review of the evidence and standards for the delivery of care. Gynecol Oncol 105(3):747-756

Furumai R, Matsuyama A, Kobashi N, Lee KH, Nishiyama M, Nakajima H, Tanaka A, Komatsu Y, Nishino N, Yoshida M, Horinouchi S (2002) FK228 (depsipeptide) as a natural prodrug that inhibits class I histone deacetylases. Cancer Res 62(17):4916-4921
Gavalas NG, Liontos M, Trachana SP, Bagratuni T, Arapinis C, Liacos C, Dimopoulos MA, Bamias A (2013) Angiogenesis-related pathways in the pathogenesis of ovarian cancer. Int J Mol Sci 14(8):15885-15909

Gayther SA, Pharoah PD (2010) The inherited genetics of ovarian and endometrial cancer. Curr Opin Genet Dev 20(3):231-238

Gayther SA, Song H, Ramus SJ, Kjaer SK, Whittemore AS, Quaye L, Tyrer J, Shadforth D, Hogdall E, Hogdall C, Blaeker J, DiCioccio R, McGuire V, Webb PM, Beesley J, Green AC, Whiteman DC, Australian Ovarian Cancer Study G, Goodman MT, Lurie G, Carney ME, Modugno F, Ness RB, Edwards RP, Moysich KB, Goode EL, Couch FJ, Cunningham JM, Sellers TA, Wu AH, Pike MC, Iversen ES, Marks JR, Garcia-Closas M, Brinton L, Lissowska J, Peplonska B, Easton DF, Jacobs I, Ponder BA, Schildkraut J, Pearce CL, Chenevix-Trench G, Berchuck A, Pharoah PD, Ovarian Cancer Association C (2007). Tagging single nucleotide polymorphisms in cell cycle control genes and susceptibility to invasive epithelial ovarian cancer. Cancer Res 67(7): 3027-3035

Gayther SA, Mangion J, Russell P, Seal S, Barfoot R, Ponder BA, Stratton MR, Easton D (1997) Variation of risks of breast and ovarian cancer associated with different germline mutations of the BRCA2 gene. Nat Genet 15(1):103-105

Glaser KB, Staver MJ, Waring JF, Stender J, Ulrich RG, Davidsen SK (2003) Gene expression profiling of multiple histone deacetylase (HDAC) inhibitors: defining a common gene set produced by HDAC inhibition in T24 and MDA carcinoma cell lines. Mol Cancer Ther 2(2):151-163

Goff BA, Mandel LS, Drescher CW, Urban N, Gough S, Schurman KM, Patras J, Mahony BS, Andersen MR (2007) Development of an ovarian cancer symptom index: possibilities for earlier detection. Cancer 109(2):221-227

Gomez-Raposo C, Mendiola M, Barriuso J, Hardisson D, Redondo A (2010) Molecular characterization of ovarian cancer by geneexpression profiling. Gynecol Oncol 118(1):88-92

Graff JR, Herman JG, Lapidus RG, Chopra H, Xu R, Jarrard DF, Isaacs WB, Pitha PM, Davidson NE, Baylin SB (1995) E-cadherin expression is silenced by DNA hypermethylation in human breast and prostate carcinomas. Cancer Res 55(22):5195-5199

Gregoire S, Yang XJ (2005) Association with class IIa histone deacetylases upregulates the sumoylation of MEF2 transcription factors. Mol Cell Biol 25(6):2273-2287

Grozinger CM, Hassig CA, Schreiber SL (1999) Three proteins define a class of human histone deacetylases related to yeast Hdalp. Proc Natl Acad Sci USA 96(9):4868-4873

Hait NC, Allegood J, Maceyka M, Strub GM, Harikumar KB, Singh SK, Luo C, Marmorstein R, Kordula T, Milstien S, Spiegel S (2009) Regulation of histone acetylation in the nucleus by sphingosine-1-phosphate. Science 325(5945):1254-1257

Havrilesky L, Darcy k M, Hamdan H, Priore RL, Leon J, Bell J, Berchuck A, S. Gynecologic Oncology Group (2003) Prognostic significance of p53 mutation and p53 overexpression in advanced epithelial ovarian cancer: a Gynecologic Oncology Group Study. J Clin Oncol 21(20): 3814-382

Hayashi A, Horiuchi A, Kikuchi N, Hayashi T, Fuseya C, Suzuki A, Konishi I, Shiozawa T (2010) Type-specific roles of histone deacetylase (HDAC) overexpression in ovarian carcinoma: HDAC1 enhances cell proliferation and HDAC3 stimulates cell migration with downregulation of E-cadherin. Int J Cancer 127(6): 1332-1346

Herzog TJ, Pothuri B (2006) Ovarian cancer: a focus on management of recurrent disease. Nat Clin Pract Oncol 3(11):604-611

Hu E, Dul E, Sung CM, Chen Z, Kirkpatrick R, Zhang GF, Johanson K, Liu R, Lago A, Hofmann G, Macarron R, de los Frailes M, Perez P, Krawiec J, Winkler J, Jaye M (2003) Identification of 
novel isoform-selective inhibitors within class I histone deacetylases. J Pharmacol Exp Ther 307(2):720-728

Huang BH, Laban M, Leung CH, Lee L, Lee CK, Salto-Tellez M, Raju GC, Hooi SC (2005) Inhibition of histone deacetylase 2 increases apoptosis and p21Cip1/WAF1 expression, independent of histone deacetylase 1. Cell Death Differ 12(4):395-404

Hwang JJ, Kim YS, Kim MJ, Jang S, Lee JH, Choi J, Ro S, Hyun YL, Lee JS, Kim CS (2009) A novel histone deacetylase inhibitor, CG0006, induces cell death through both extrinsic and intrinsic apoptotic pathways. Anticancer Drugs 20(9):815-821

Karlan BY, Oza AM, Richardson GE, Provencher DM, Hansen VL, Buck M, Chambers SK, Ghatage P, Pippitt CH Jr, Brown JV 3rd, Covens A, Nagarkar RV, Davy M, Leath CA 3rd, Nguyen H, Stepan DE, Weinreich DM, Tassoudji M, Sun YN, Vergote IB (2012) Randomized, double-blind, placebo-controlled phase II study of AMG 386 combined with weekly paclitaxel in patients with recurrent ovarian cancer. J Clin Oncol 30(4):362-371

Kartalou M, Essigmann JM (2001) Mechanisms of resistance to cisplatin. Mutat Res 478(1-2):23-43

Khabele D, Son DS, Parl AK, Goldberg GL, Augenlicht LH, Mariadason JM, Rice VM (2007) Drug-induced inactivation or gene silencing of class I histone deacetylases suppresses ovarian cancer cell growth: implications for therapy. Cancer Biol Ther 6(5):795-801

Kim MS, Blake M, Baek JH, Kohlhagen G, Pommier Y, Carrier F (2003) Inhibition of histone deacetylase increases cytotoxicity to anticancer drugs targeting DNA. Cancer Res 63(21):7291-7300

Klug TL, Bast RC Jr, Niloff JM, Knapp RC, Zurawski VR Jr (1984) Monoclonal antibody immunoradiometric assay for an antigenic determinant (CA 125) associated with human epithelial ovarian carcinomas. Cancer Res 44(3):1048-1053

Kolasa IK, Rembiszewska A, Janiec-Jankowska A, Dansonka-Mieszkowska A, Lewandowska AM, Konopka B, Kupryjanczyk J (2006) PTEN mutation, expression and LOH at its locus in ovarian carcinomas. Relation to TP53, K-RAS and BRCA1 mutations. Gynecol Oncol 103(2):692-697

Kudoh K, Takano M, Kouta H, Kikuchi R, Kita T, Miyamoto M, Watanabe A, Kato M, Goto T, Kikuchi Y (2011) Effects of bevacizumab and pegylated liposomal doxorubicin for the patients with recurrent or refractory ovarian cancers. Gynecol Oncol 122(2):233-237

Kurian AW, Balise RR, McGuire V, Whittemore AS (2005) Histologic types of epithelial ovarian cancer: Have they different risk factors? Gynecol Oncol 96(2):520-530

Lane AA, Chabner BA (2009) Histone deacetylase inhibitors in cancer therapy. J Clin Oncol 27(32):5459-5468

Leitao MM, Soslow RA, Baergen RN, Olvera N, Arroyo C, Boyd J (2004) Mutation and expression of the TP53 gene in early stage epithelial ovarian carcinoma. Gynecol Oncol 93(2):301-306

Lin CT, Lai HC, Lee HY, Lin WH, Chang CC, Chu TY, Lin YW, Lee KD, Yu MH (2008) Valproic acid resensitizes cisplatin-resistant ovarian cancer cells. Cancer Sci 99(6):1218-1226

Lowe KA, Andersen MR, Urban N, Paley P, Dresher CW, Goff BA (2009) The temporal stability of the Symptom Index among women at high-risk for ovarian cancer. Gynecol Oncol $114(2): 225-230$

MacDonald JL, Roskams AJ (2008) Histone deacetylases 1 and 2 are expressed at distinct stages of neuro-glial development. Dev Dyn 237(8):2256-2267

Mai A, Massa S, Pezzi R, Simeoni S, Rotili D, Nebbioso A, Scognamiglio A, Altucci L, Loidl P, Brosch G (2005) Class II (IIa)-selective histone deacetylase inhibitors. 1. Synthesis and biological evaluation of novel (aryloxopropenyl)pyrrolyl hydroxyamides. J Med Chem 48(9):3344-3353

Marcus CS, Maxwell GL, Darcy KM, Hamilton CA, McGuire WP (2014) Current approaches and challenges in managing and monitoring treatment response in ovarian cancer. J Cancer 5(1):25-30
Markman M (2001) Intraperitoneal chemotherapy is appropriate first line therapy for patients with optimally debulked ovarian cancer. Crit Rev Oncol Hematol 38(3):171-175

Marks P, Rifkind RA, Richon VM, Breslow R, Miller T, Kelly WK (2001) Histone deacetylases and cancer: causes and therapies. Nat Rev Cancer 1(3):194-202

Marsden DE, Friedlander M, Hacker NF (2000) Current management of epithelial ovarian carcinoma: a review. Semin Surg Oncol 19(1):11-19

Matei D, Sill MW, Lankes HA, DeGeest K, Bristow RE, Mutch D, Yamada SD, Cohn D, Calvert V, Farley J, Petricoin EF, Birrer MJ (2011) Activity of sorafenib in recurrent ovarian cancer and primary peritoneal carcinomatosis: a gynecologic oncology group trial. J Clin Oncol 29(1):69-75

McGonigle KF, Muntz HG, Vuky J, Paley PJ, Veljovich DS, Greer BE, Goff BA, Gray HJ, Malpass TW (2011) Combined weekly topotecan and biweekly bevacizumab in women with platinumresistant ovarian, peritoneal, or fallopian tube cancer: results of a phase 2 study. Cancer 117(16):3731-3740

Meyer T, Rustin GJ (2000) Role of tumour markers in monitoring epithelial ovarian cancer. Br J Cancer 82(9):1535-1538

Modesitt SC, Sill M, Hoffman JS, Bender DP, Gynecologic Oncology G (2008) A phase II study of vorinostat in the treatment of persistent or recurrent epithelial ovarian or primary peritoneal carcinoma: a Gynecologic Oncology Group study. Gynecol Oncol 109(2):182-186

Morrison J, Swanton A, Collins S, Kehoe S (2007) Chemotherapy versus surgery for initial treatment in advanced ovarian epithelial cancer. Cochrane Database Syst Rev 4:CD005343

Mottet D, Pirotte S, Lamour V, Hagedorn M, Javerzat S, Bikfalvi A, Bellahcene A, Verdin E, Castronovo V (2009) HDAC4 represses p21(WAF1/Cip1) expression in human cancer cells through a Sp1-dependent, p53-independent mechanism. Oncogene 28(2):243-256

Naora H, Montell DJ (2005) Ovarian cancer metastasis: integrating insights from disparate model organisms. Nat Rev Cancer 5(5):355-366

Ohmichi M, Hayakawa J, Tasaka K, Kurachi H, Murata Y (2005) Mechanisms of platinum drug resistance. Trends Pharmacol Sci 26(3):113-116

Ozaki K, Kishikawa F, Tanaka M, Sakamoto T, Tanimura S, Kohno M (2008) Histone deacetylase inhibitors enhance the chemosensitivity of tumor cells with cross-resistance to a wide range of DNA-damaging drugs. Cancer Sci 99(2):376-384

Ozols RF, Bundy BN, Greer BE, Fowler JM, Clarke-Pearson D, Burger RA, Mannel RS, DeGeest K, Hartenbach EM, Baergen R (2003) Phase III trial of carboplatin and paclitaxel compared with cisplatin and paclitaxel in patients with optimally resected stage III ovarian cancer: a Gynecologic Oncology Group study. J Clin Oncol 21(17):3194-3200

Palmer JE, Sant Cassia LJ, Irwin CJ, Morris AG, Rollason TP (2008) P53 and bcl-2 assessment in serous ovarian carcinoma. Int J Gynecol Cancer 18(2):241-248

Permuth-Wey J, Sellers TA (2009) Epidemiology of ovarian cancer. Methods Mol Biol 472:413-437

Perren TJ, Swart AM, Pfisterer J, Ledermann JA, Pujade-Lauraine E, Kristensen G, Carey MS, Beale P, Cervantes A, Kurzeder C, du Bois A, Sehouli J, Kimmig R, Stahle A, Collinson F, Essapen S, Gourley C, Lortholary A, Selle F, Mirza MR, Leminen A, Plante M, Stark D, Qian W, Parmar MK, Oza AM (2011) A phase 3 trial of bevacizumab in ovarian cancer. N Engl J Med 365(26):2484-2496

Piccart MJ, Lamb H, Vermorken JB (2001) Current and future potential roles of the platinum drugs in the treatment of ovarian cancer. Ann Oncol 12(9):1195-1203

Piek JM, Dorsman JC, Shvarts A, Ansink AC, Massuger LF, Scholten P, van Diest PJ, Dijkstra JC, Weegenaar J, Kenemans 
P, Verheijen RH (2004) Cultures of ovarian surface epithelium from women with and without a hereditary predisposition to develop female adnexal carcinoma. Gynecol Oncol 92(3):819-826

Piperno G, LeDizet M, Chang XJ (1987) Microtubules containing acetylated alpha-tubulin in mammalian cells in culture. J Cell Biol 104(2):289-302

Plisiecka-Halasa J, Karpinska G, Szymanska T, Ziolkowska I, Madry R, Timorek A, Debniak J, Ulanska M, Jedryka M, ChudeckaGlaz A, Klimek M, Rembiszewska A, Kraszewska E, Dybowski B, Markowska J, Emerich J, Pluzanska A, Goluda M, RzepkaGorska I, Urbanski K, Zielinski J, Stelmachow J, Chrabowska M, Kupryjanczyk J (2003) P21WAF1, P27KIP1, TP53 and C-MYC analysis in 204 ovarian carcinomas treated with platinum-based regimens. Ann Oncol 14(7):1078-1085

Prat J, Ribe A, Gallardo A (2005) Hereditary ovarian cancer. Hum Pathol 36(8):861-870

Qian X, LaRochelle WJ, Ara G, Wu F, Petersen KD, Thougaard A, Sehested M, Lichenstein HS, Jeffers M (2006) Activity of PXD101, a histone deacetylase inhibitor, in preclinical ovarian cancer studies. Mol Cancer Ther 5(8):2086-2095

Rauh-Hain JA, Krivak TC, Del Carmen MG, Olawaiye AB (2011) Ovarian cancer screening and early detection in the general population. Rev Obstet Gynecol 4(1):15-21

Ribeiro JR, Lovasco LA, Vanderhyden BC, Freiman RN (2014) Targeting TBP-associated factors in ovarian cancer. Front Oncol $4: 45$

Rinaldi S, Dossus L, Lukanova A, Peeters PH, Allen NE, Key T, Bingham S, Khaw KT, Trichopoulos D, Trichopoulou A, Oikonomou E, Pera G, Larranaga N, Martinez-Garcia C, Ardanaz E, Quiros JR, Tormo MJ, Tjonneland A, Olsen A, Overvad K, ChangClaude J, Linseisen J, Schulz M, Boeing H, van Gils $\mathrm{CH}$, Bueno-de-Mesquita BH, Pala V, Palli D, Panico S, Tumino R, Vineis P, Clavel-Chapelon F, Mesrine S, Boutron-Ruault MC, Lundin E, Agren A, Berglund G, Manjer J, Kumle M, Lund E, Slimani N, Saracci R, Riboli E, Kaaks R (2007) Endogenous androgens and risk of epithelial ovarian cancer: results from the European Prospective Investigation into Cancer and Nutrition (EPIC). Cancer Epidemiol Biomarkers Prev 16(1):23-29

Risch HA (1998) Hormonal etiology of epithelial ovarian cancer, with a hypothesis concerning the role of androgens and progesterone. J Natl Cancer Inst 90(23):1774-1786

Saito A, Yamashita T, Mariko Y, Nosaka Y, Tsuchiya K, Ando T, Suzuki T, Tsuruo T, Nakanishi O (1999) A synthetic inhibitor of histone deacetylase, MS-27-275, with marked in vivo antitumor activity against human tumors. Proc Natl Acad Sci USA 96(8):4592-4597

Sawada K, Mitra AK, Radjabi AR, Bhaskar V, Kistner EO, Tretiakova M, Jagadeeswaran S, Montag A, Becker A, Kenny HA, Peter ME, Ramakrishnan V, Yamada SD, Lengyel E (2008) Loss of E-cadherin promotes ovarian cancer metastasis via alpha 5-integrin, which is a therapeutic target. Cancer Res 68(7):2329-2339

Scanlan MJ, Welt S, Gordon CM, Chen YT, Gure AO, Stockert E, Jungbluth AA, Ritter G, Jager D, Jager E, Knuth A, Old LJ (2002) Cancer-related serological recognition of human colon cancer: identification of potential diagnostic and immunotherapeutic targets. Cancer Res 62(14):4041-4047

Schuijer M, Berns EM (2003) TP53 and ovarian cancer. Hum Mutat 21(3):285-291

Secrist JP, Zhou X, Richon VM (2003) HDAC inhibitors for the treatment of cancer. Curr Opin Investig Drugs 4(12):1422-1427

Senese S, Zaragoza K, Minardi S, Muradore I, Ronzoni S, Passafaro A, Bernard L, Draetta GF, Alcalay M, Seiser C, Chiocca S (2007) Role for histone deacetylase 1 in human tumor cell proliferation. Mol Cell Biol 27(13):4784-4795

Shebzukhov YV, Koroleva EP, Khlgatian SV, Belousov PV, Kuz'mina KE, Radko BV, Longpre F, Lagarkova MA, Kadachigova TS,
Gurova OV, Meshcheryakov AA, Lichinitser MR, Knuth A, Jager E, Kuprash DV, Nedospasov SA (2005) Antibody response to a non-conserved C-terminal part of human histone deacetylase 3 in colon cancer patients. Int J Cancer 117(5):800-806

Smolle E, Taucher V, Petru E, Haybaeck J (2014) Targeted treatment of ovarian cancer-the multiple-kinase-inhibitor sorafenib as a potential option. Anticancer Res 34(4):1519-1530

Sonnemann J, Gange J, Pilz S, Stotzer C, Ohlinger R, Belau A, Lorenz G, Beck JF (2006) Comparative evaluation of the treatment efficacy of suberoylanilide hydroxamic acid (SAHA) and paclitaxel in ovarian cancer cell lines and primary ovarian cancer cells from patients. BMC Cancer 6:183

Sorbe B, Graflund M, Horvath G, Swahn M, Boman K, Bangshoj R, Lood M, Malmstrom H (2012) Phase II study of docetaxel weekly in combination with carboplatin every 3 weeks as firstline chemotherapy in stage IIB to stage IV epithelial ovarian cancer. Int J Gynecol Cancer 22(1):47-53

Spiegel S, Milstien S, Grant S (2012) Endogenous modulators and pharmacological inhibitors of histone deacetylases in cancer therapy. Oncogene 31(5):537-551

Strahl BD, Allis CD (2000) The language of covalent histone modifications. Nature 403(6765):41-45

Stratton JF, Gayther SA, Russell P, Dearden J, Gore M, Blake P, Easton D, Ponder BA (1997) Contribution of BRCA1 mutations to ovarian cancer. N Engl J Med 336(16):1125-1130

Struhl K (1998) Histone acetylation and transcriptional regulatory mechanisms. Genes Dev 12(5):599-606

Strumberg D, Richly H, Hilger RA, Schleucher N, Korfee S, Tewes M, Faghih M, Brendel E, Voliotis D, Haase CG, Schwartz B, Awada A, Voigtmann R, Scheulen ME, Seeber S (2005) Phase I clinical and pharmacokinetic study of the Novel Raf kinase and vascular endothelial growth factor receptor inhibitor BAY 43-9006 in patients with advanced refractory solid tumors. J Clin Oncol 23(5):965-972

Takai N, Narahara H (2007) Human endometrial and ovarian cancer cells: histone deacetylase inhibitors exhibit antiproliferative activity, potently induce cell cycle arrest, and stimulate apoptosis. Curr Med Chem 14(24):2548-2553

Takai N, Kawamata N, Gui D, Said JW, Miyakawa I, Koeffler HP (2004) Human ovarian carcinoma cells: histone deacetylase inhibitors exhibit antiproliferative activity and potently induce apoptosis. Cancer 101(12):2760-2770

Takai N, Ueda T, Nishida M, Nasu K, Narahara H (2006) A novel histone deacetylase inhibitor, Scriptaid, induces growth inhibition, cell cycle arrest and apoptosis in human endometrial cancer and ovarian cancer cells. Int J Mol Med 17(2):323-329

Tortolero-Luna G, Mitchell MF (1995) The epidemiology of ovarian cancer. J Cell Biochem Suppl 23:200-207

Tothill RW, Tinker AV, George J, Brown R, Fox SB, Lade S, Johnson DS, Trivett MK, Etemadmoghadam D, Locandro B, Traficante N, Fereday S, Hung JA, Chiew YE, Haviv I, Australian Ovarian Cancer Study G, Gertig D, DeFazio A, Bowtell DD (2008) Novel molecular subtypes of serous and endometrioid ovarian cancer linked to clinical outcome. Clin Cancer Res 14(16):5198-5208

Tuxen MK, Soletormos G, Dombernowsky P (1995) Tumor markers in the management of patients with ovarian cancer. Cancer Treat Rev 21(3):215-245

Vannini A, Volpari C, Filocamo G, Casavola EC, Brunetti M, Renzoni D, Chakravarty P, Paolini C, De Francesco R, Gallinari P, Steinkuhler C, Di Marco S (2004) Crystal structure of a eukaryotic zinc-dependent histone deacetylase, human HDAC8, complexed with a hydroxamic acid inhibitor. Proc Natl Acad Sci USA 101(42):15064-15069

Verdin E, Dequiedt F, Kasler HG (2003) Class II histone deacetylases: versatile regulators. Trends Genet 19(5):286-293 
Villar-Garea A, Esteller M (2004) Histone deacetylase inhibitors: understanding a new wave of anticancer agents. Int $\mathrm{J}$ Cancer 112(2):171-178

Walker JL, Armstrong DK, Huang HQ, Fowler J, Webster K, Burger RA, Clarke-Pearson D (2006) Intraperitoneal catheter outcomes in a phase III trial of intravenous versus intraperitoneal chemotherapy in optimal stage III ovarian and primary peritoneal cancer: a Gynecologic Oncology Group Study. Gynecol Oncol 100(1):27-32

Waltregny D, Glenisson W, Tran SL, North BJ, Verdin E. Colige A, Castronovo V (2005) Histone deacetylase HDAC8 associates with smooth muscle alpha-actin and is essential for smooth muscle cell contractility. FASEB J 19(8):966-968

Wang PH, Chang C (2004) Androgens and ovarian cancers. Eur J Gynaecol Oncol 25(2):157-163

Warrell RP Jr, He LZ, Richon V, Calleja E, Pandolfi PP (1998) Therapeutic targeting of transcription in acute promyelocytic leukemia by use of an inhibitor of histone deacetylase. J Natl Cancer Inst 90(21):1621-1625

Wedge SR, Kendrew J, Hennequin LF, Valentine PJ, Barry ST, Brave SR, Smith NR, James NH, Dukes M, Curwen JO, Chester R, Jackson JA, Boffey SJ, Kilburn LL, Barnett S, Richmond GH, Wadsworth PF, Walker M, Bigley AL, Taylor ST, Cooper L, Beck S, Jurgensmeier JM, Ogilvie DJ (2005) AZD2171: a highly potent, orally bioavailable, vascular endothelial growth factor receptor-2 tyrosine kinase inhibitor for the treatment of cancer. Cancer Res 65(10):4389-4400

Weichert W, Denkert C, Noske A, Darb-Esfahani S, Dietel M, Kalloger SE, Huntsman DG, Kobel M (2008) Expression of class I histone deacetylases indicates poor prognosis in endometrioid subtypes of ovarian and endometrial carcinomas. Neoplasia 10(9):1021-1027

Wernyj RP, Morin PJ (2004) Molecular mechanisms of platinum resistance: still searching for the Achilles' heel. Drug Resist Updates 7(4-5):227-232

Wilson AJ, Byun DS, Popova N, Murray LB, L'Italien K, Sowa Y, Arango D, Velcich A, Augenlicht LH, Mariadason JM (2006) Histone deacetylase 3 (HDAC3) and other class I HDACs regulate colon cell maturation and p21 expression and are deregulated in human colon cancer. J Biol Chem 281(19):13548-13558

Zhang J, Chen YL, Ji G, Fang W, Gao Z, Liu Y, Wang J, Ding X, Gao F (2013) Sorafenib inhibits epithelial-mesenchymal transition through an epigenetic-based mechanism in human lung epithelial cells. PLoS ONE 8(5):e64954

Zhu P, Martin E, Mengwasser J, Schlag P, Janssen KP, Gottlicher M (2004) Induction of HDAC2 expression upon loss of APC in colorectal tumorigenesis. Cancer Cell 5(5):455-463 